\title{
Synthesis and Application of A Fluorescent Substrate Analogue to Study Ligand Interactions for Undecaprenyl Pyrophosphate Synthase
}

\author{
Annie P.-C. Chen, ${ }^{\dagger}$ Yi-Hung Chen,,$\$$, Hsiao-Pei Liu,,$\S$ Yu-Chin Li,, \\ Chao-Tsen Chen, ${ }^{*}$, and Po-Huang Liang ${ }^{*}, \neq, \uparrow$ \\ Contribution from the Institute of Biological Chemistry, Academia Sinica, Taipei 11529, \\ Institute of Biochemical Sciences, and Department of Chemistry, National Taiwan University, \\ Taipei 10098, Taiwan
}

Received July 9, 2002

\begin{abstract}
Farnesyl pyrophosphate (FPP) serves as a common substrate for many prenyltransferases involved in the biosynthesis of isoprenoid compounds. Undecaprenyl pyrophosphate synthase (UPPs) catalyzes the chain elongation of FPP to $\mathrm{C}_{55}$ undecaprenyl pyrophosphate (UPP) which acts as a lipid carrier in bacterial peptidoglycan synthesis. In this study, 7-(2,6-dimethyl-8-diphospho-2,6-octadienyloxy)8-methyl-4-trifluoromethyl-chromen-2-one geranyl pyrophosphate, a fluorescent analogue of FPP, was prepared and utilized to study ligand interactions with E. coli UPPs. This compound displays an absorbance maximum at $336 \mathrm{~nm}$ and emission maximum at $460 \mathrm{~nm}$ without interference from protein autofluorescence. It is a competitive inhibitor with respect to $\operatorname{FPP}\left(K_{\mathrm{i}}=0.57 \mu \mathrm{M}\right)$ and also serves as an alternative substrate $\left(K_{\mathrm{m}}=0.69 \mu \mathrm{M}\right.$ and $\left.k_{\text {cat }}=0.02 \mathrm{~s}^{-1}\right)$, but mainly reacts with one isopentenyl pyrophosphate (IPP) probably due to unfavorable product translocation. Fluorescence intensity of this compound is reduced when bound to the enzyme (1:1 stoichiometry), and is recovered by FPP replacement. Using stopped-flow apparatus, the interaction of enzyme with the compound was measured $\left(k_{\mathrm{on}}=55.3 \mu \mathrm{M}^{-1} \mathrm{~s}^{-1}\right.$ and $\left.k_{\mathrm{off}}=31.6 \mathrm{~s}^{-1}\right)$. The product dissociation rate constant $\left(0.5 \mathrm{~s}^{-1}\right)$ determined from the competition experiments is consistent with our previous prediction from kinetic simulation. Unlike several other prenyltransferase reactions in which FPP dissociates slowly, UPPs binds FPP in a rapid equilibrium manner with a fast release rate constant of $30 \mathrm{~s}^{-1}$. The fluorescent analogue of FPP presented here may provide a tool to investigate the ligand interactions for a broad class of FPP-binding proteins.
\end{abstract}

\section{Introduction}

Farnesyl pyrophosphate (FPP) serves as a branch point to synthesize a variety of natural isoprenoids. ${ }^{1-3}$ This compound is synthesized by farnesyl pyrophosphate synthase (FPPs) via coupling of isopentenyl pyrophosphate (IPP) with its isomer, dimethylallyl pyrophosphate, followed by condensation of another IPP. ${ }^{4,5}$ Starting from FPP, many linear isoprenoid compounds with various chain lengths are generated by multiple condensations with IPP catalyzed by a group of prenyltransferases. ${ }^{6,7}$ Undecaprenyl pyrophosphate synthase (UPPs) is one member of these prenyltransferases, which produces $\mathrm{C}_{55}$ un-

* To whom correspondence should be addressed. Tel: 886-2-27855696 ext. 6070. Fax: 886-2-2788-9759. E-mail: phliang @gate.sinica.edu.tw; Tel: 886-2-2364-5819. Fax: 886-2-2363-6359. E-mail: ctchen@ mail.ch.ntu.edu.tw.

Institute of Biochemical Sciences, National Taiwan University.

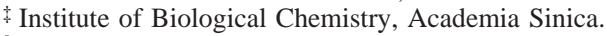

$\S$ Department of Chemistry, National Taiwan University.

(1) Kellogg, B. A.; Poulter, C. D. Curr. Opin. Chem. Biol. 1997, 1, 570-578

(2) Ogura, K.; Koyama, T.; Sagami, H. Subcellular Biochem. 1997, 28, chapter $3,57-87$

(3) Liang, P. H.; Ko, T. P.; Wang, A. H.-J. Eur. J. Biochem. 2002, 269, 33393354 .

(4) Eberhardt, L.; Rilling, H. C. J. Biol. Chem. 1975, 250, 863-866.

(5) Poulter, C. D.; Rilling, H. C. In Biosynthesis of Isoprenoid Compounds: Porter, J. W., Spurgeon, S. L., Eds.; Wiley: New York, 1981; Vol 1, pp $161-224$

10.1021/ja020937v CCC: $\$ 22.00 \odot 2002$ American Chemical Society decaprenyl pyrophosphate (UPP) via consecutive condensation reactions of eight IPP with a FPP. The enzyme product acts as the carrier to transport lipid II to extracellular compartments for the synthesis of bacterial peptidoglycan. ${ }^{8}$ Because of its pivotal role in cell wall biosynthesis, the enzyme is essential for bacterial survival and could be regarded as an antibiotic drug target. There is a need for convenient methodology to monitor its inhibitor binding activities.

UPPs is the most well studied cis-prenyltransferase that shows no sequence homology with the trans enzymes such as FPPs (cis and trans enzymes catalyze the formation of cis and trans double bonds in the IPP condensation reactions, respectively). ${ }^{9,10}$ We have previously determined rate constant for each IPP condensation catalyzed by UPPs using pre-steady-state kinetic approach. ${ }^{11}$ However, the substrate and product dissociation kinetics were not examined due to the complexity of 8-step UPPs reaction and incapability of using isotope trapping

(6) Ogura, K.; Koyama, T. Chem. Rev. 1998, 98, 1263-1276.

(7) Wang, K. C.; Ohnuma, S.-I. Biochim. Biophys. Acta 2000, 1529, 33-48.

(8) Robyt, J. In Essentials of Carbohydrate Chemistry; Springer-Verlag: New York, 1998; Chapter 10, pp 305-318.

(9) Shimizu, N.; Koyama, T.; Ogura, K. J. Biol. Chem. 1998, 273, 19 47619481.

(10) Apfel, C. M.; Takacs, B.; Fountoulakis, M.; Stieger, M.; Keck, W. J. Bacteriol. 1999, 181, 483-492. 
experiments to determine rapid substrate release rate and binding order. In an isotope trapping experiment, one isotope-labeled substrate preincubated with the enzyme is mixed with the second substrate and a large excess of unlabeled first substrate. ${ }^{12}$ Upon mixing the two solutions, labeled substrate that dissociates from the $\mathrm{E} \cdot \mathrm{S}$ complex prior to its conversion to product is diluted into the pool of unlabeled substrate and its specificity is reduced to a negligible level. The amount of label in the product reflects the rate of $\mathrm{E} \cdot \mathrm{S}$ conversion to product relative to that of $\mathrm{E} \cdot \mathrm{S}$ dissociation. Using this method, FPP has been characterized in the yeast Ras farnesyltransferase reaction as a "sticky" substrate with slow dissociation rate $\left(k_{\text {off }}=0.48 \mathrm{~s}^{-1}\right)$ from enzyme active site. ${ }^{13}$ The allylic substrate geranyl pyrophosphate is also released from FPPs slowly with a $k_{\text {off }}=1.4 \mathrm{~s}^{-1} \cdot{ }^{14}$ A method is desired to overcome the obstacle in measuring kinetics of FPP dissociation from UPPs. Such a method also allows the kinetic parameter determination of a slow product dissociation originated from the strong hydrophobic interaction of the enzyme with the product. ${ }^{15}$

To serve the above needs, in this study we have designed and synthesized a novel fluorescent analogue of FPP containing a chromen-2-one fluorophore. This analogue

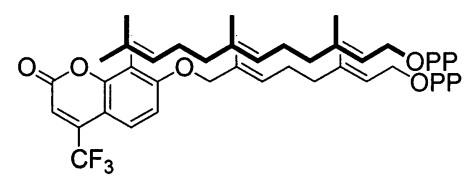

features similar carbon skeleton as the substrate FPP (shown in bold) and acts as an inhibitor and an alternative substrate for UPPs. The electron-withdrawing $\mathrm{CF}_{3}$ group shifts the excitation and emission maxima to longer wavelengths and prevents interference from protein autofluorescence. Chromenone fluorophore typically displays fluorescence intensity change depending on the nature of the environment. ${ }^{16-18}$ Previously, the $\mathrm{N}$-methylanthraniloyl fluorescent analogues of geranylgeranyl pyrophosphate and FPP were prepared and utilized to probe the phosphoisoprenoid binding specificity of geranylgeranyltransferase type II that belongs to another class of prenyltransferases involved in the signal transduction. ${ }^{19,20}$ Geranylgeranyl pyrophosphate fluorescent analogues containing highly conjugated double bonds were also synthesized, which could be possibly used for studying the interaction and subcellular localization of prenylated small GTPase proteins in signaling complexes. ${ }^{21}$ In the present study, by taking the advantage of the synthetic compound's intrinsic fluorescence change upon binding to the enzyme, the ligand interactions of UPPs were examined. The fluorescent probe provides an immediate and

(11) Pan, J. J.; Chiou, S. T.; Liang, P. H. Biochemistry 2000, 39, 10 936-10942.

(12) Rose, I. A. Methods Enzymol. 1980, 64, 47-59.

(13) Mathis, J. R.; Poulter, C. D. Biochemistry 1997, 36, 6367-6376

(14) Laskovics, F. M.; Poulter, C. D. Biochemistry 1981, 20, 1893-1901.

(15) Ko, T. P.; Chen, Y. K.; Robinson, H.; Tsai, P. C.; Gao, Y.-G.; Chen, A. P.-C.; Wang, A. H.-J.; Liang, P. H. J. Biol. Chem. 2001, 276, $47474-$ 47482.

(16) Reichardt, C.Chem. Rev. 1994, 94, 2319-2358.

(17) Kosower, E. M.; Mohammad, M. J. Am. Chem. Soc. 1971, 93, 27132719.

(18) Kamlet, M. J.; Abboud, J.-L. M.; Taft, R. W. J. Am. Chem. Soc. 1977, 99, $8325-8327$

(19) Owen, D. J.; Alexandrov, K.; Rostkova, E.; Scheidig, A. J.; Goody, R. S.; Waldmann, H. Angew. Chem., Int. Ed. Engl. 1999, 38, 509-512.

(20) Thoma, N. H.; Iakovenko, A.; Owen, D.; Scheidig, A. S.; Waldmann, H.; Goody, R. S.; Alexandrov, K. Biochemistry 2000, 39, $12043-12052$.

(21) Liu, X.-H.; Prestwich, G. D. J. Am. Chem. Soc. 2001, 124, 20-21. continuous signal, allowing real-time monitoring of the processes by stopped-flow and steady-state fluorimeters.

\section{Materials and Methods}

Reagents and General Methods. Geraniol, 3,4-dihydropyran (DHP), pyridinium $p$-toluenesulfonate (PPTs), tert-butyl hydroperoxide, selenium dioxide, salicylic acid, $N$-bromosuccinimide (NBS), dimethyl sulfide, and tris-(tetra- $n$-butylammonium) diphosphate were purchased from Aldrich. Dowex AG50 $\times 8$ ion exchange column $\left(\mathrm{NH}_{4}{ }^{+}\right.$form $)$ was obtained from Sigma. The radiolabeled $\left[{ }^{14} \mathrm{C}\right] \mathrm{IPP}(55 \mathrm{mCi} / \mathrm{mmol})$ was purchased from Amersham Pharmacia Biotech. The all-trans-FPP and IPP were obtained from Sigma. $(S)$-farnesyl thiopyrophosphate (FsPP) was synthesized previously. ${ }^{22}$ Reversed-phase thin-layer chromatography (TLC) plate is the product of Merck Chemical Co. The NiNTA resin was obtained from Qiagen and potato acidic phosphatase (2 Unit/mg) was purchased from Boehringer Mannheim. All commercial buffers, solvents, and reagents are of the highest grade. UPPs was prepared according to previous procedure. ${ }^{23}$

NMR measurements were performed on Bruker AVANCE spectrometer operating at $400 \mathrm{MHz}$. Mass analysis was carried out using JEOL-SX102A instrument. FT-IR spectra were recorded using Nicolet magna-IR 550 series II. For HPLC chromatography, a Waters system with a reverse phase Hypersil HS C8 column $(250 \times 4.6 \mathrm{~mm})$ obtained from ThermoQuest was used.

Synthesis of Compound 8. Synthesis of the fluorescent substrate analogue was carried out using 7-step procedures starting from commercially available geraniol as described below.

3,7-Dimethyl-1-[(tetrahydro-2H-pyran-2-yl)oxy]-(E)-2,6-octandiene (2). To a solution of geraniol $(6.23 \mathrm{~g}, 40.0 \mathrm{mmol})$ in $\mathrm{CH}_{2} \mathrm{Cl}_{2}(40$ $\mathrm{mL}$ ) were added DHP (4.08 g, $48.0 \mathrm{mmol})$ and PPTs (1.05 g, 4.0 mmol); the resulting solution was stirred at $27{ }^{\circ} \mathrm{C}$ for $4 \mathrm{~h}$. The reaction mixture was partially evaporated, diluted with ethyl acetate, and washed with saturated $\mathrm{NaHCO}_{3}$ aqueous solution. The organic layer was dried over $\mathrm{MgSO}_{4}$, and concentrated to afford colorless oil. The residue was purified by flash chromatography on silica gel to yield compound 2 (8.57 g, 90\%): TLC (EtOAc/Hexane, $1: 10, \mathrm{v} / \mathrm{v}) R_{f} 0.5 ;{ }^{1} \mathrm{H}$ NMR (400 $\left.\mathrm{MHz}, \mathrm{CDCl}_{3}\right) \delta 1.48-1.84(\mathrm{~m}, 15 \mathrm{H}), 2.00-2.10(\mathrm{~m}, 4 \mathrm{H}), 3.46-3.51$ $(\mathrm{m}, 1 \mathrm{H}), 3.85-3.90(\mathrm{~m}, 1 \mathrm{H}), 3.99-4.04(\mathrm{~m}, 1 \mathrm{H}), 4.19-4.23(\mathrm{~m}, 1 \mathrm{H})$, $4.59-4.61(\mathrm{~m}, 1 \mathrm{H}), 5.07(\mathrm{t}, 1 \mathrm{H}, J=6.9 \mathrm{~Hz}), 5.34(\mathrm{t}, 1 \mathrm{H}, J=6.9 \mathrm{~Hz})$; ${ }^{13} \mathrm{C}$ NMR $\left(100 \mathrm{MHz}, \mathrm{CDCl}_{3}\right) \delta 16.38,17.66,19.63,25.51,25.66,26.37$, $30.73,62.28,63.63,97.76,120.62,124.04,131.58,140.19$; HRMS (FAB): $m / z$ calcld for $\mathrm{C}_{15} \mathrm{H}_{26} \mathrm{O}_{2}\left(\mathrm{M}^{+}\right)$238.1933, found 238.1931; FTIR (KBr) 2944, 2858, 1672, $1454 \mathrm{~cm}^{-1}$.

2,6-Dimethyl-8-[(tetrahydro-2H-pyran-2-yl)oxy]-(E)-2,6-octandien1-ol (3). To a solution of compound 2 (7.52 g, $31.5 \mathrm{mmol})$ in $\mathrm{CH}_{2} \mathrm{Cl}_{2}$ $(40 \mathrm{~mL})$ were added tert-butyl hydroperoxide $(14 \mathrm{~mL}, 100.7 \mathrm{mmol})$, selenium dioxide $(0.35 \mathrm{~g}, 3.15 \mathrm{mmol})$, and salicylic acid $(0.44 \mathrm{~g}, 3.15$ mmol). The resultant solution was stirred at $27{ }^{\circ} \mathrm{C}$ for $12 \mathrm{~h}$, and the excess solvent was then removed by a rotary evaporator. tert-Butyl hydroperoxide was removed by repeated washing with toluene. The residue was dissolved in $\mathrm{Et}_{2} \mathrm{O}$, and then washed with saturated $\mathrm{NaHCO}_{3}$ aqueous solution to remove selenium dioxide. The organic layer was then dried over $\mathrm{MgSO}_{4}$, concentrated and the crude product was purified by flash chromatography on silica gel to yield compound 3 (2.56 g, $32 \%)$ TLC (EtOAc/Hexane, 1:5, v/v) $R_{f} 0.3 ;{ }^{1} \mathrm{H}$ NMR $(400 \mathrm{MHz}$, $\left.\mathrm{CDCl}_{3}\right) \delta 1.48-1.81(\mathrm{~m}, 12 \mathrm{H}), 2.04-2.17(\mathrm{~m}, 4 \mathrm{H}), 3.47-3.50(\mathrm{~m}$, $1 \mathrm{H}), 3.84-3.87(\mathrm{~m}, 1 \mathrm{H}), 3.97(\mathrm{~s}, 2 \mathrm{H}), 3.98-4.02(\mathrm{~m}, 1 \mathrm{H}), 4.19-4.24$ $(\mathrm{m}, 1 \mathrm{H}), 4.59-4.61(\mathrm{~m}, 1 \mathrm{H}), 5.32-5.38(\mathrm{~m}, 2 \mathrm{H}) ;{ }^{13} \mathrm{C} \mathrm{NMR}(100 \mathrm{MHz}$, $\left.\mathrm{CDCl}_{3}\right) \delta 13.69,16.34,19.60,25.49,25.75,30.69,39.14,62.29,63.70$, 69.02, 97.87, 121.06, 125.72, 135.14, 139.64; HRMS (FAB): $\mathrm{m} / \mathrm{z}$ calculated for $\mathrm{C}_{15} \mathrm{H}_{26} \mathrm{O}_{3}\left(\mathrm{M}^{+}\right)$254.1882, found 255.1961; FT-IR (KBr) $3463,2946,2873,1678,1443 \mathrm{~cm}^{-1}$.

(22) Chen, Y. H.; Chen, A. P.-C.; Chen, C.-T.; Wang, A. H.-J.; Liang, P. H. J. Biol. Chem. 2002, 277, 7369-7376.

(23) Pan, J. J.; Yang, L. W.; Liang, P. H. Biochemistry 2000, 39, $13856-$ 13861 . 
1-Bromo-2,6-dimethyl-8-[(tetrahydro-2H-pyran-2-yl)oxy]-(E)-2,6octandiene (4). NBS (1.22 g, $6.85 \mathrm{mmol})$ dissolving in $\mathrm{CH}_{2} \mathrm{Cl}_{2}(10$ $\mathrm{mL})$ was added dimethyl sulfide $(0.53 \mathrm{~g}, 8.56 \mathrm{mmol})$ under argon at $-35{ }^{\circ} \mathrm{C}$ and the reaction was maintained at this temperature for additional $1 \mathrm{~h}$ before warmed up to $0{ }^{\circ} \mathrm{C}$. The reaction was then cooled to $-35{ }^{\circ} \mathrm{C}$ prior to the introduction of compound $3(1.43 \mathrm{~g}, 5.62 \mathrm{mmol})$ in $\mathrm{CH}_{2} \mathrm{Cl}_{2}(5 \mathrm{~mL})$ dropwise followed by slowly warming up to $27^{\circ} \mathrm{C}$ within an hour. The reaction was worked up by pouring the reaction mixture into saturated $\mathrm{NaHCO}_{3}$ aqueous solution. Extractions were performed with ethyl acetate and the combined organic layers were dried over $\mathrm{MgSO}_{4}$, and concentrated. The crude product was purified by flash chromatography on silica gel to yield compound 4 (1.64 g, 92\%): TLC (EtOAc/Hexane, 1:8, v/v) $R_{f} 0.4 ;{ }^{1} \mathrm{H}$ NMR $(400 \mathrm{MHz}$, $\left.\mathrm{CDCl}_{3}\right) \delta 1.48-1.83(\mathrm{~m}, 12 \mathrm{H}), 2.04-2.17(\mathrm{~m}, 4 \mathrm{H}), 3.47-3.50(\mathrm{~m}$, $1 \mathrm{H}), 3.84-3.89(\mathrm{~m}, 1 \mathrm{H}), 3.94(\mathrm{~s}, 2 \mathrm{H}), 3.98-4.03(\mathrm{~m}, 1 \mathrm{H}), 4.19-4.24$ $(\mathrm{m}, 1 \mathrm{H}), 4.59-4.61(\mathrm{~m}, 1 \mathrm{H}), 5.34(\mathrm{t}, 1 \mathrm{H}, J=6.8 \mathrm{~Hz}), 5.56(\mathrm{t}, 1 \mathrm{H}$, $J=6.7 \mathrm{~Hz}) ;{ }^{13} \mathrm{C} \mathrm{NMR}\left(100 \mathrm{MHz}, \mathrm{CDCl}_{3}\right) \delta 14.67,16.39,19.63,25.50$, 26.53, 30.72, 38.66, 41.67, 62.31, 63.62, 97.90, 121.24, 130.81, 132.24, 139.26; HRMS (FAB): $\mathrm{m} / z$ calculated for $\mathrm{C}_{15} \mathrm{H}_{26} \mathrm{BrO}_{2}\left(\mathrm{M}^{+}\right)$316.1038, found 317.1107; FT-IR (KBr) 2946, 2874, 1432, $1379 \mathrm{~cm}^{-1}$.

7-[(2,6-Dimethyl-8-(tetrahydro-2H-pyran-2-yl)oxy)-2,6-octadienyloxy]-8-methyl-4-trifluoromethyl-chromen-2-one (5). Compound 4 $(0.61 \mathrm{~g}, 1.92 \mathrm{mmol})$ and anhydrous $\mathrm{K}_{2} \mathrm{CO}_{3}(0.41 \mathrm{~g}, 3 \mathrm{mmol})$ were added to a solution of 7-hydroxy-8-methyl-4-trifluoromethyl coumarin $(0.52$ $\mathrm{g}, 2.11 \mathrm{mmol}$ ) in $5 \mathrm{~mL}$ DMF. 7-Hydroxy-8-methyl-4-trifluoromethyl coumarin was prepared using a reported reaction condition. ${ }^{24}$ The resultant solution was stirred at $27^{\circ} \mathrm{C}$ for $4 \mathrm{~h}$. The reaction mixture was then poured into ice-water, extracted with ethyl acetate, and dried over $\mathrm{MgSO}_{4}$. The organic layer was concentrated and purified by flash chromatography on silica gel to yield compound $\mathbf{5}$ as a clear oil (94\%): TLC (EtOAc/Hexane, 1:9, v/v) $R_{f} 0.3 ;{ }^{1} \mathrm{H}$ NMR $(400 \mathrm{MHz}$, $\left.\mathrm{CDCl}_{3}\right) \delta 1.47-1.84(\mathrm{~m}, 15 \mathrm{H}), 2.06-2.24(\mathrm{~m}, 4 \mathrm{H}), 2.31(\mathrm{~s}, 3 \mathrm{H}), 3.48-$ $3.52(\mathrm{~m}, 1 \mathrm{H}), 3.84-3.89(\mathrm{~m}, 1 \mathrm{H}), 3.97-4.02(\mathrm{~m}, 1 \mathrm{H}), 4.20-4.25(\mathrm{~m}$, $1 \mathrm{H}), 4.49(\mathrm{~s}, 2 \mathrm{H}) 4.59-4.61(\mathrm{~m}, 1 \mathrm{H}), 5.35(\mathrm{t}, 1 \mathrm{H}, J=6.9 \mathrm{~Hz}), 5.53$ $(\mathrm{t}, 1 \mathrm{H}, J=6.4 \mathrm{~Hz}), 6.59(\mathrm{~s}, 1 \mathrm{H}), 6.85(\mathrm{~d}, 1 \mathrm{H}, J=9.0 \mathrm{~Hz}), 7.50(\mathrm{~d}$, $1 \mathrm{H}, J=9.0 \mathrm{~Hz}) ;{ }^{13} \mathrm{C} \mathrm{NMR}\left(100 \mathrm{MHz}, \mathrm{CDCl}_{3}\right) \delta 8.32,13.79,16.41$, $19.65,25.48,25.89,30.71,38.95,62.36,63.65,74.59,97.98,107.15$, $108.89,111.97(\mathrm{q}, J=5.9 \mathrm{~Hz}), 115.18,121.14,121.75(\mathrm{q}, J=273.9$ $\mathrm{Hz}), 123.33(\mathrm{q}, J=2.3 \mathrm{~Hz}), 128.92,130.37,139.45,141.84(\mathrm{~d}, J=$ $32.2 \mathrm{~Hz}), 153.50,159.77,160.55 ;{ }^{19} \mathrm{~F}$ NMR $\left(\mathrm{MHz}, \mathrm{CDCl}_{3}\right) \delta-65.37$; HRMS (FAB): $m / z$ calculated for $\mathrm{C}_{26} \mathrm{H}_{31} \mathrm{~F}_{3} \mathrm{O}_{5}\left(\mathrm{M}^{+}\right)$480.2124, found 481.2200; FT-IR (KBr) 2931, 2874, 1747, 1608, 1573, $1508 \mathrm{~cm}^{-1}$.

7-(2,6-Dimethyl-8-hydroxy-2,6-octadienyloxy)-8-methyl-4-trifluoromethyl-chromen-2-one (6). To a solution of compound $5(0.43 \mathrm{~g}$, $1.01 \mathrm{mmol})$ in ethanol $(6 \mathrm{~mL})$ was added PPTs $(25 \mathrm{mg}, 0.10 \mathrm{mmol})$ and the reaction was stirred at $55^{\circ} \mathrm{C}$ for $8 \mathrm{~h}$. Solvent was reduced to one-half by a rotary evaporator and the remaining solution was diluted with $\mathrm{CH}_{2} \mathrm{Cl}_{2}$ and washed with brine to remove PPTs. The organic layer was then dried over $\mathrm{MgSO}_{4}$, and concentrated to afford crude product, which was further purified by flash chromatography on silica gel to yield compound $\mathbf{6}$ as a white solid (92\%): TLC (EtOAc/Hexane, 1:3, v/v) $R_{f} 0.2 ;{ }^{1} \mathrm{H} \mathrm{NMR}\left(400 \mathrm{MHz}, \mathrm{CDCl}_{3}\right) \delta 1.67(\mathrm{~s}, 3 \mathrm{H}), 1.73(\mathrm{~s}, 3 \mathrm{H})$, $2.06-2.24(\mathrm{~m}, 4 \mathrm{H}), 2.31(\mathrm{~s}, 3 \mathrm{H}), 4.14(\mathrm{~d}, 2 \mathrm{H}, J=6.8 \mathrm{~Hz}), 4.49(\mathrm{~s}$, 2H), $5.40(\mathrm{t}, 1 \mathrm{H}, J=6.9 \mathrm{~Hz}), 5.53(\mathrm{t}, 1 \mathrm{H}, J=7.0 \mathrm{~Hz}), 6.59(\mathrm{~s}, 1 \mathrm{H})$, $6.85(\mathrm{~d}, 1 \mathrm{H}, J=9.0 \mathrm{~Hz}), 7.51(\mathrm{~d}, 1 \mathrm{H}, J=9.0 \mathrm{~Hz}) ;{ }^{13} \mathrm{C}$ NMR $(100$ $\left.\mathrm{MHz}, \mathrm{CDCl}_{3}\right) \delta 8.21,13.74,16.17,25.86,38.84,59.14,74.52,107.03$, $108.89,111.82(\mathrm{q}, J=5.5 \mathrm{~Hz}), 115.04,121.69(\mathrm{q}, J=274.0 \mathrm{~Hz})$, $123.29(\mathrm{q}, J=2.0 \mathrm{~Hz}), 123.97,128.79,130.40,138.48,141.77$ (q, $J=32.3 \mathrm{~Hz}), 153.38,159.77,160.51$; HRMS (FAB): $\mathrm{m} / \mathrm{z}$ calculated for $\mathrm{C}_{21} \mathrm{H}_{23} \mathrm{~F}_{3} \mathrm{O}_{4}\left(\mathrm{M}^{+}\right)$396.1548, found 397.1622; FT-IR (KBr) 3433, 2978, 2934, 2865, 1745, 1607, $1573 \mathrm{~cm}^{-1}$.

7-(8-Bromo-2,6-dimethyl-2,6-octadienyloxy)-8-methyl-4-trifluoromethyl-chromen-2-one (7). To a solution of compound $6(0.17 \mathrm{~g}$,

(24) Xie, L.; Takeuchi, Y.; Cosentino, L. M.; McPhail, A. T.; Lee, K.-H. J. Med. Chem. 2001, 44, 664-671.
$0.50 \mathrm{mmol})$ in $\mathrm{CH}_{2} \mathrm{Cl}_{2}(4 \mathrm{~mL})$ were added $\mathrm{CBr}_{4}(0.20 \mathrm{~g}, 0.6 \mathrm{mmol})$ and $\mathrm{PPh}_{3}(0.16 \mathrm{~g}, 0.6 \mathrm{mmol})$. The mixture was stirred under argon for $4 \mathrm{~h}$ at $27^{\circ} \mathrm{C}$. The solution was concentrated to afford crude product, which was purified by flash chromatography on silica gel to yield compound 7 as a colorless oil (80\%): TLC (EtOAc/Hexane, 1:4, v/v) $R_{f} 0.3 ;{ }^{1} \mathrm{H}$ NMR $\left(400 \mathrm{MHz}, \mathrm{CDCl}_{3}\right) \delta 1.71(\mathrm{~s}, 3 \mathrm{H}), 1.72$ (s, 3H), 2.08$2.22(\mathrm{~m}, 4 \mathrm{H}), 2.29(\mathrm{~s}, 3 \mathrm{H}), 3.98(\mathrm{~d}, 2 \mathrm{H}, J=8.4 \mathrm{~Hz}), 4.49(\mathrm{~s}, 2 \mathrm{H})$, $5.48-5.52(\mathrm{~m}, 2 \mathrm{H}), 6.59(\mathrm{~s}, 1 \mathrm{H}), 6.86(\mathrm{~d}, 1 \mathrm{H}, J=9.0 \mathrm{~Hz}), 7.51(\mathrm{~d}$, $1 \mathrm{H}, J=9.0 \mathrm{~Hz}) ;{ }^{13} \mathrm{C} \mathrm{NMR}\left(100 \mathrm{MHz}, \mathrm{CDCl}_{3}\right) \delta 8.32,13.81,15.92$, 25.68, 29.36, 38.82, 74.44, 107.13, 108.90, $111.97(\mathrm{q}, J=5.7 \mathrm{~Hz})$, $115.15,121.08,121.74(\mathrm{q}, J=274.0 \mathrm{~Hz}), 123.29(\mathrm{~d}, J=2.2 \mathrm{~Hz})$, $128.24,130.74,141.80$ (q, $J=32.3 \mathrm{~Hz}), 142.76,153.488,159.71$, 160.50; HRMS (FAB): $m / z$ calculated for $\mathrm{C}_{21} \mathrm{H}_{22} \mathrm{BrF}_{3} \mathrm{O}_{3}\left(\mathrm{M}^{+}\right)$458.0704, found 459.0786; FT-IR (KBr) 2932, 2864, 1746, 1607, $1573 \mathrm{~cm}^{-1}$.

7-(2,6-Dimethyl-8-diphospho-2,6-octadienyloxy)-8-methyl-4-trifluoromethyl-chromen-2-one (8). A solution of compound 7 (85 mg, $0.21 \mathrm{mmol}$ ) in $1 \mathrm{~mL}$ acetonitrile was added dropwise to the solution of tris-(tetra- $n$-butylammonium) diphosphate $(0.55 \mathrm{~g}, 0.6 \mathrm{mmol})$ in 3 $\mathrm{mL}$ acetonitrile at $25{ }^{\circ} \mathrm{C}$, which was prepared according to a reported procedure. ${ }^{25}$ The mixture was stirred at $27^{\circ} \mathrm{C}$ for $6 \mathrm{~h}$. The organic solvent was then removed by a rotary evaporator and the residue was dissolved in small amount of deionized water prior to passing through a short Dowex AG50X8 ion exchange column $\left(\mathrm{NH}_{4}{ }^{+}\right.$form). The filtrate was lyophilized to yield a white solid, which was further purified by reversed-phase HPLC using a program of $20 \%$ B for 5 min, followed by a linear gradient of $20 \% \mathrm{~B}$ to $60 \% \mathrm{~B}$ over $20 \mathrm{~min}$ with a flow rate of $2.5 \mathrm{~mL} / \mathrm{min}$ [A, $25 \mathrm{mM}$ aqueous ammonium bicarbonate $(\mathrm{pH} 8.0)$; $\mathrm{B}$, acetonitrile]. The desired fractions were collected and lyophilized to afford compound 8 as a white solid $(46 \%)$ : ${ }^{1} \mathrm{H}$ NMR $(400 \mathrm{MHz}$, $\left.\mathrm{D}_{2} \mathrm{O}\right) \delta 1.71(\mathrm{~s}, 6 \mathrm{H}), 2.05(\mathrm{~s}, 3 \mathrm{H}), 2.08-2.25(\mathrm{~m}, 4 \mathrm{H}), 4.45-4.49(\mathrm{~m}$, $4 \mathrm{H}), 5.45(\mathrm{t}, 1 \mathrm{H}, J=7.2 \mathrm{~Hz}), 5.57(\mathrm{t}, 1 \mathrm{H}, J=7.0 \mathrm{~Hz}), 6.59(\mathrm{~s}, 1 \mathrm{H})$, $6.89(\mathrm{~d}, 1 \mathrm{H}, J=9.1 \mathrm{~Hz}), 7.44(\mathrm{~d}, 1 \mathrm{H}, J=9.1 \mathrm{~Hz}) ;{ }^{13} \mathrm{C} \mathrm{NMR}(100$ $\left.\mathrm{MHz}, \mathrm{D}_{2} \mathrm{O}\right) \delta 7.33,13.02,15.68,25.67,38.47,62.54,73.86,106.13$, $108.55,111.02,114.26,119.75(\mathrm{q}, J=8.3 \mathrm{~Hz}), 121.26(\mathrm{q}, J=273.5$ $\mathrm{Hz}), 122.85,128.45,130.13,141.11(\mathrm{q}, J=33.0 \mathrm{~Hz}), 141.80,152.37$, 159.86, 159.95; ${ }^{31} \mathrm{P}$ NMR $\left(266 \mathrm{MHz}, \mathrm{D}_{2} \mathrm{O}\right) \delta-9.30(\mathrm{~d}, J=34.3 \mathrm{~Hz})$, $-10.31(\mathrm{~d}, J=34.3 \mathrm{~Hz})$; UV $\left(\mathrm{H}_{2} \mathrm{O}\right), \lambda_{\max }=336 \mathrm{~nm}, \epsilon=12416$ $\mathrm{M}^{-1} \mathrm{~cm}^{-1}$, HRMS(FAB): $\mathrm{m} / \mathrm{z}$ calculated for $\mathrm{C}_{21} \mathrm{H}_{25} \mathrm{~F}_{3} \mathrm{O}_{10} \mathrm{P}_{2}\left(\mathrm{M}^{+}\right)$ 556.0875, found 557.0961; FT-IR (KBr) 3445, 3172, 1736, 1609, 1400 $\mathrm{cm}^{-1}$.

Measurement of Inhibition Constant for Compound 8. The measurement of inhibition constant for compound $\mathbf{8}$ was performed in a reaction mixture containing $0.03 \mu \mathrm{M}$ UPPs, $3 \mu \mathrm{M}$ FPP and $50 \mu \mathrm{M}$ $\left[{ }^{14} \mathrm{C}\right] \mathrm{IPP}$ in a buffer of $100 \mathrm{mM}$ Hepes- $\mathrm{KOH}(\mathrm{pH} 7.5), 50 \mathrm{mM} \mathrm{KCl}$, $0.5 \mathrm{mM} \mathrm{MgCl}_{2}$, and $0.1 \%$ Triton $\mathrm{X}-100$ in the presence of various concentrations of the inhibitor. The $0.1 \%$ Triton $\mathrm{X}-100$ was included in the reaction so that the product release was not limiting the reaction; thus allowed the measurement of IPP condensation rate at each inhibitor concentration. Portions of reaction mixture periodically withdrawn were mixed with $10 \mathrm{mM}$ EDTA to terminate the reaction and 1-butanol was utilized to extract the enzyme products for quantification using scintillation counting. The initial rate was obtained for zero and different concentration $(0-7.5 \mu \mathrm{M})$ of the inhibitor and $K_{\mathrm{i}}$ value of the inhibitor was determined by fitting reaction rate versus the inhibitor concentration using the following equations. ${ }^{26}$

$$
\begin{gathered}
A(I)=A(0) \times\left\{1-\left[\mathrm{I} /\left(\mathrm{I}+K_{\mathrm{i}}\left(1+S / K_{\mathrm{m}}\right)\right)\right]\right\} \\
\mathrm{IC}_{50}=K_{\mathrm{i}}\left(1+S / K_{\mathrm{m}}\right)
\end{gathered}
$$

In these equations, $A(I)$ is the enzyme activity with the inhibitor concentration $I, A(0)$ is enzyme activity without inhibitor, $I$ is the

(25) Davisson, V. J.; Woodside, A. B.; Neal, T. R.; Stremler, K. E.; Muehlbacher, M.; Poulter, C. D. J. Org. Chem. 1986, 51, 4768-4779. 
inhibitor concentration, $K_{\mathrm{i}}$ is the inhibition constant of the inhibitor, $\mathrm{S}$ is FPP concentration, and $K_{\mathrm{m}}$ is Michaelis constant of FPP.

Kinetic Parameter Measurements of 8 as Alternative Substrate. In a reaction mixture containing $0.1 \mu \mathrm{M}$ UPPs, $50 \mu \mathrm{M}\left[{ }^{14} \mathrm{C}\right] \mathrm{IPP}, 0.5$ $\mathrm{mM} \mathrm{MgCl} 2,50 \mathrm{mM} \mathrm{KCl}$ and $0.1 \%$ Triton X-100 in $100 \mathrm{mM}$ Hepes$\mathrm{KOH}(\mathrm{pH} 7.5)$ at $25^{\circ} \mathrm{C}, 0.5-5 \mu \mathrm{M}$ of $\mathbf{8}$ was added to initiate the enzyme reaction for the measurements of $K_{\mathrm{m}}$ and $k_{\text {cat }}$ values. The 40 $\mu \mathrm{L}$ portions of reaction mixture were withdrawn and mixed with 10 $\mathrm{mM}$ EDTA to stop the enzyme reaction. The enzyme initial rate at each substrate concentration was determined as described above within the first $10 \%$ substrate depletion. The plot of initial rate vs concentration of the substrate fitted with the Michaelis-Menten equation (eq 3) gave $K_{\mathrm{m}}$ and $k_{\text {cat }}\left(V_{\max } /[\mathrm{E}]\right)$ values

$$
v_{\mathrm{o}}=V_{\max }[\mathrm{S}] /\left(K_{\mathrm{m}}+[\mathrm{S}]\right)
$$

where $v_{\mathrm{o}}$ is the initial velocity, [E] is the enzyme concentration, [S] is the substrate concentration, $V_{\max }$ is the maximum velocity and $K_{\mathrm{m}}$ is the Michaelis constant.

Reaction Products of $\mathbf{8}$ with IPP. To monitor enzyme products, compound $8(4 \mu \mathrm{M})$ was incubated with UPPs $(10 \mu \mathrm{M})$ and $\left[{ }^{14} \mathrm{C}\right] \mathrm{IPP}$ $(50 \mu \mathrm{M})$ for various periods of time from 10 to $250 \mathrm{~s}$ and then manually quenched with $10 \mathrm{mM}$ EDTA to stop the reaction. The reaction was carried out under single enzyme turnover to monitor the IPP condensation of $\mathbf{8}$ in the active site. Product analysis was carried out by converting the products to the corresponding alcohols by treatment with potato acidic phosphatase. ${ }^{27}$ The resulting alcohols were separated on the reverse phase TLC plate and visualized by a bioimaging analyzer (Fujifilm BAS-1500).

To verify the product of $\mathbf{8}$ with unlabeled IPP, the primary product was extracted with butanol and further purified using a reverse phase HPLC. Its parent ion mass was measured by a Mass spectroscopic analysis.

Photospectroscopies and Quantum Yield of 8. The absorption spectra of compounds 8 in ethanol, $\mathrm{H}_{2} \mathrm{O}$ and DMSO $(1 \mu \mathrm{M})$ were taken on a UV-vis spectrophotometer (HP 8453, Hewlett-Packard). Their fluorescence emission spectra were recorded on a Hitachi F-4500 spectrophotometer from 400 to $550 \mathrm{~nm}$ by using $336 \mathrm{~nm}$ as the excitation wavelength. Quantum yield of the compound was determined in ethanol using $1 \mu \mathrm{M}$ coumarin 1 as the reference standard. ${ }^{28}$

Fluorescence Titration and Stoichiometry Determination. The fluorescence spectra of $1 \mu \mathrm{M}$ compound in a buffer containing 100 $\mathrm{mM}$ Hepes- $\mathrm{KOH}$ (pH 7.5), $0.5 \mathrm{MgCl}_{2}$ and $50 \mathrm{mM} \mathrm{KCl}$ at $25^{\circ} \mathrm{C}$ were measured prior to and after the addition of $1 \mu \mathrm{M}$ UPPs. The spectra were also recorded after adding $0.6,1.2$, and $3 \mu \mathrm{M}$ FPP into the binary complex of the enzyme and $\mathbf{8}$ to observe the gradual recovery of fluorescence by FPP replacement. To determine the stoichiometry of 8 binding with UPPs, the fluorescence intensity at $460 \mathrm{~nm}$ of compound $8(0.5 \mu \mathrm{M})$ when excited at its $\lambda_{\mathrm{ex}}{ }^{\max } 336 \mathrm{~nm}$ was recorded after each addition of UPPs solution $(0.2-3 \mu \mathrm{M})$ at $25^{\circ} \mathrm{C}$. The titration curve was fitted with a quadratic equation using software OriginR 6.0 (Microcal) to provide an estimation of stoichiometry. ${ }^{29}$

Stopped-Flow Experiments. Stopped-flow measurements were performed as described previously. ${ }^{22}$ Compound $\mathbf{8}$ fluorescence above $530 \mathrm{~nm}$ with a cut off filter was monitored using an excitation wavelength of $336 \mathrm{~nm}$. In the measurements of observed binding rate, the stopped-flow experiments were performed by mixing different concentration of UPPs $(2.5,5,7.5$, and $10 \mu \mathrm{M})$ with equal volume of 8 solution $(0.5 \mu \mathrm{M})$ in a buffer containing $100 \mathrm{mM}$ Hepes- $\mathrm{KOH}(\mathrm{pH}$

(26) Segel, I. H. In Enzyme Kinetics: Behavior and Analysis of Rapid Equilibrium and Steady-State Enzyme Systems; Classics Library, ed.; John Wiley and Sons: New York, 1993; pp 100-118.

(27) Fujii, H.; Koyama, T.; Ogura, K. Biochim. Biophys. Acta 1982, 712, 716718.

(28) Lakowicz, J. R. In Principles of Fluorescecne Spectroscopy, 2nd ed.; Kluwer: New York, 1999; Chapter 2, pp 52-59.

(29) Bourson, J.; Pouget, J.; Valeur, B. J. Phys. Chem. 1993, 97, 4552-4557.
7.5), $0.5 \mathrm{mM} \mathrm{MgCl}_{2}$ and $50 \mathrm{mM} \mathrm{KCl}$. The concentrations of enzyme, FPP, compound 8, and IPP cited in the parentheses and hereafter in the text are those after mixing. Apparent observed rate was obtained by fitting the stopped-flow trace (average of four repeated runs) with a single-exponential equation using the software provided by Applied Photophysics. The slope of $k_{\text {obs }}$ vs enzyme concentration yielded the rate constant $\left(k_{\mathrm{on}}\right)$ of the compound binding to UPPs.

In the measurement of dissociation rate constant $\left(k_{\text {off }}\right)$, compound $\mathbf{8}$ $(0.75 \mu \mathrm{M})$ preincubated with UPPs $(0.5 \mu \mathrm{M})$ was mixed with excess of FPP $(25 \mu \mathrm{M})$ to displace the compound from the enzyme. The stopped-flow trace was fitted with a single-exponential equation to obtain the $k_{\text {off }}$ of compound $\mathbf{8}$. In a similar manner, FPP dissociation rate constant was obtained by mixing $\operatorname{FPP}(0.75 \mu \mathrm{M})$ preincubated with UPPs $(0.5 \mu \mathrm{M})$ with compound $8(20 \mu \mathrm{M})$. To measure the substrate release rate in the presence of IPP, the FsPP $(1 \mu \mathrm{M})$ preincubated with both enzyme $(0.5 \mu \mathrm{M})$ and IPP $(5 \mu \mathrm{M})$ was mixed with compound 8 $(20 \mu \mathrm{M})$. The decrease of fluorescence was recorded with time and fitted with a single-exponential equation.

UPP product dissociation constant was determined by using compound $\mathbf{8}$ as a competing agent. FPP $(0.75 \mu \mathrm{M})$ and IPP $(6 \mu \mathrm{M})$ were incubated with UPPs $(0.2 \mu \mathrm{M})$ in buffer containing $25 \mathrm{mM}$ Tris- $\mathrm{HCl}$ (pH 7.5), $5 \mathrm{mM} \mathrm{MgCl}$, and $50 \mathrm{mM} \mathrm{KCl}$, for $10 \mathrm{~min}$ to ensure the formation of product in the enzyme active site. The solution was then mixed using the stopped-flow apparatus with excess of compound $\mathbf{8}$ $(15 \mu \mathrm{M})$ to displace the product from the enzyme. The singleexponential equation was utilized to fit the stopped-flow data to obtain the product $k_{\text {off }}$ value.

\section{Results}

Synthesis and Spectroscopic Characterization of Compound $\mathbf{8}$. The synthetic route to $\mathbf{8}$ is outlined in Scheme 1 . Starting from commercially available geraniol, hydroxy group was protected by reaction with DHP and PPTs to generate tetrahydropyranyl ether (compound 2) in good yield. The resulting ether was selectively oxidized with tert-butyl hydroperoxide and catalytic $\mathrm{SeO}_{2} \cdot \mathrm{H}_{2} \mathrm{O}$ to give the allylic alcohol (compound 3), which was further converted to the corresponding bromide (compound 4) by treating with NBS and dimethyl sulfide in a similar condition previously employed..$^{30-32}$ Subsequent incorporation of 7-hydroxy-8-methyl-4-trifluoromethyl coumarin was accomplished by Williamson etherification. Deprotection of the DHP group by PPTs gave the desired 6 in quantitative yield. Bromination of $\mathbf{6}$ with tetrabromomethane and triphenylphosphine followed by the displacement of the bromide with tris(tetra- $n$-butylammonium) hydrogen pyrophosphate generated the target molecule, which was then purified by using reversed-phase chromatography. The total yield of the compound $\mathbf{8}$ from the starting material is $8.1 \%$. In aqueous solution, compound $\mathbf{8}$ displays red-shifted $\lambda_{\mathrm{ex}}{ }^{\max }=336 \mathrm{~nm}$ $\left(\epsilon_{336}=1.24 \times 10^{4} \mathrm{M}^{-1} \mathrm{~cm}^{-1}\right)$ and $\lambda_{\mathrm{em}}{ }^{\max }=460 \mathrm{~nm}$ due to the electron-withdrawing $\mathrm{CF}_{3}$ that stabilizes the lowest unoccupied molecular orbital (LUMO) energy level. Another compound we synthesized with $\mathrm{CH}_{3}$ in place of $\mathrm{CF}_{3}$ shows shorter $\lambda_{\mathrm{ex}}{ }^{\max }$ at $322 \mathrm{~nm}\left(\epsilon_{322}=2.01 \times 10^{4} \mathrm{M}^{-1} \mathrm{~cm}^{-1}\right)$ and $\lambda_{\mathrm{em}}{ }^{\max }$ at $400 \mathrm{~nm}$ (data not shown). The $\lambda_{\mathrm{em}}{ }^{\max }$ of $\mathbf{8}$ is shifted from 460 to 435 $\mathrm{nm}$ and quantum yield is 1.6 and 16 times smaller in ethanol and in less polar DMSO, respectively (Figure S1 of the Supporting Information). These large fluorescence changes

(30) Gaon, I.; Turek, T. C.; Weller, V. A.; Edelstein, R. L.; Singh, S. K.; Distefano, M. D. J. Org. Chem. 1996, 61, 7738-7745.

(31) Turek, T. C.; Gaon, I.; Distefano, M. D. J. Org. Chem. 2001, 66, 32523264.

(32) Knight, D. W.; Rustidge, D. C. J. Chem. Soc., Perkin Trans. 1981, 1, 679683. 
Scheme 1. Synthesis of 7-(2,6-dimethyl-8-diphospho-2,6-octadienyloxy)-8-methyl-4-trifluoromethyl-chromen-2-one Geranyl Pyrophosphate (compound 8)
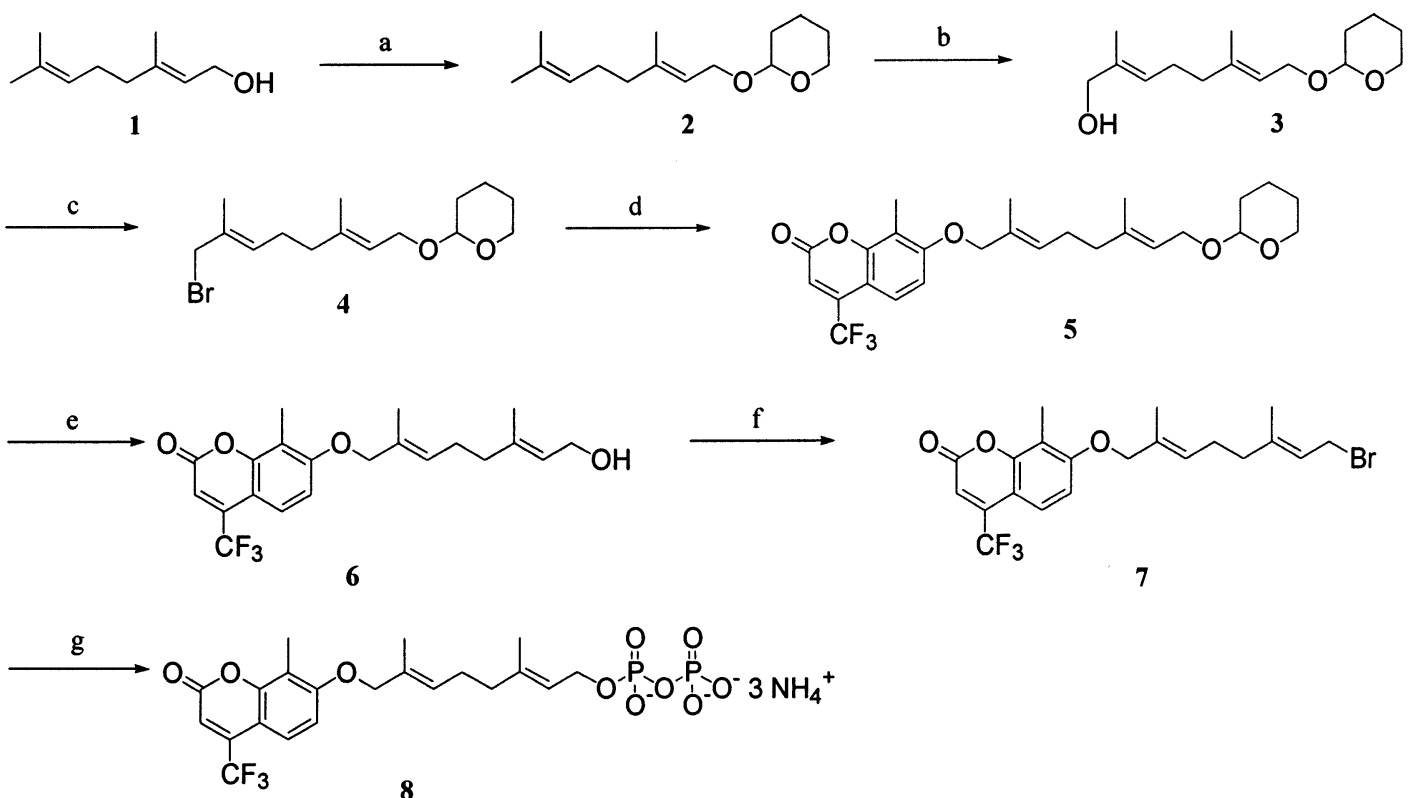

(a) DHP, PPTs, $\mathrm{CH}_{2} \mathrm{Cl}_{2}, 90 \%$; (b) $\mathrm{SeO}_{2}, t$-BuOOH, salicylic acid, $\mathrm{CH}_{2} \mathrm{Cl}_{2}, 32 \%$; (c) NBS, $\mathrm{Me}_{2} \mathrm{~S}, \mathrm{CH}_{2} \mathrm{Cl}_{2}, 92 \%$; (d) $\mathrm{K}_{2} \mathrm{CO}_{3}$, DMF, 7-hydroxy-8-methyl4-trifluorolmethylcoumarin, 94\%; (e) $\mathrm{PPTs}, \mathrm{EtOH}, 92 \%$; (f) $\mathrm{CBr}_{4}, \mathrm{PPh}_{3}, \mathrm{CH}_{2} \mathrm{Cl}_{2}, 80 \%$; and (g) $\left(n-\mathrm{Bu}_{4} \mathrm{~N}_{3} \mathrm{HP}_{2} \mathrm{O}_{7}, \mathrm{CH}_{3} \mathrm{CN}, 46 \%\right.$.

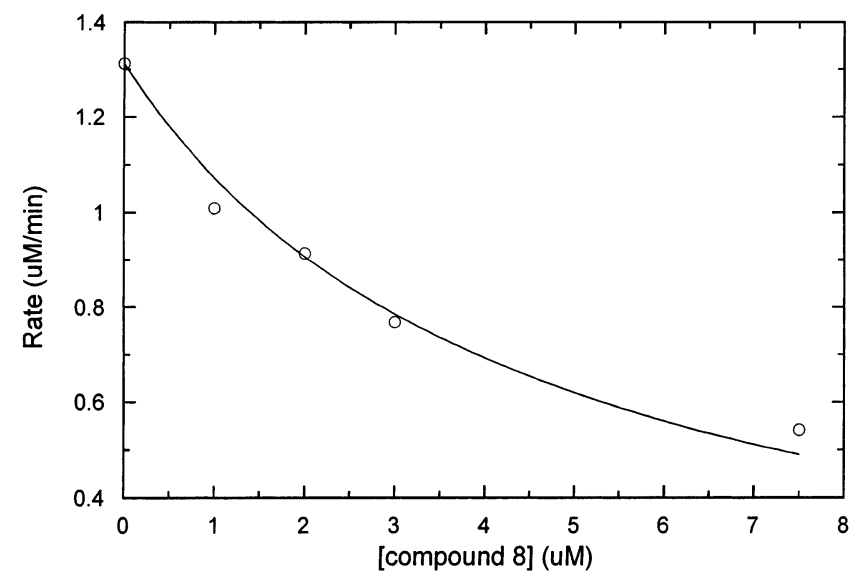

Figure 1. Inhibition of $E$. coli UPPs by compound 8 . The enzyme reactions with $0.03 \mu \mathrm{M}$ enzyme, $3 \mu \mathrm{M}$ FPP and $50 \mu \mathrm{M}\left[{ }^{14} \mathrm{C}\right] \mathrm{IPP}$ were conducted in the presence of various concentrations of inhibitor $8(0-7.5 \mu \mathrm{M})$. The plot of initial rate vs inhibitor concentration was used to determine the inhibition constant of the inhibitor.

provide sufficient sensitivity in measuring the interaction between the fluorescent probe and the protein. Moreover, its excitation exceeds $330 \mathrm{~nm}$ to prevent UV-induced protein damage, and its emission wavelength approaches $500 \mathrm{~nm}$ to avoid autofluorescence from protein itself. Compound $\mathbf{8}$ was used in the fluorescence titration and stopped-flow experiments as described below.

8 Serves as Inhibitor and Alternative Substrate for UPPs. As shown in Figure 1, the $\mathrm{IC}_{50}$ of $\mathbf{8}$ in the presence of $0.03 \mu \mathrm{M}$ enzyme, $3 \mu \mathrm{M}$ FPP and $50 \mu \mathrm{M}$ IPP is approximately $4.8 \pm 0.1$ $\mu \mathrm{M}$ which corresponds to $0.57 \pm 0.05 \mu \mathrm{M}$ of $K_{\mathrm{i}}$ value calculated from eqs 1 and 2 . We have further determined the kinetic parameters of UPPs using $\mathbf{8}$ as a substrate. The reaction is 125fold slower compared to the reaction using FPP and the $k_{\text {cat }}$ and $K_{\mathrm{m}}$ values are $0.02 \pm 0.003 \mathrm{~s}^{-1}$ and $0.69 \pm 0.1 \mu \mathrm{M}$, respectively, under the steady-state condition. The $K_{\mathrm{m}}$ of compound $\mathbf{8}$ is consistent with its $K_{\mathrm{i}}$ value and is also similar

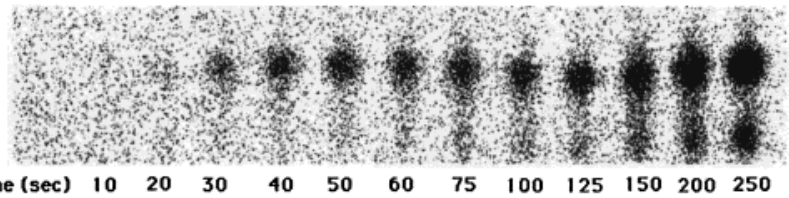

Figure 2. TLC analysis of the products formed by incubation of $4 \mu \mathrm{M}$ compound 8 with $10 \mu \mathrm{M}$ UPPs and $50 \mu \mathrm{M}\left[{ }^{14} \mathrm{C}\right] \mathrm{IPP}$ at $\mathrm{pH} 7.5$ and $25^{\circ} \mathrm{C}$ from 10 to $250 \mathrm{~s}$. The reaction products were converted to corresponding alcohols and subjected to reverse phase TLC analysis as described in Materials and Methods.

to the $K_{\mathrm{m}}(0.4 \mu \mathrm{M})$ of FPP. However, the primary product of $\mathbf{8}$ catalyzed by the enzyme is quite different from using FPP as a substrate. As shown in Figure 2, the compound condenses with one molecule of IPP more efficiently than with the second IPP under the single-turnover condition with $10 \mu \mathrm{M}$ UPPs, $4 \mu \mathrm{M}$ compound 8 and $50 \mu \mathrm{M}\left[{ }^{14} \mathrm{C}\right] \mathrm{IPP}$. Under such a condition with excessive amount of enzyme, the intermediates $\left(\mathrm{C}_{20}-\mathrm{C}_{50}\right)$ along with the product $\left(\mathrm{C}_{55}\right)$ can be seen in the time course of FPP chain elongation catalyzed by UPPs. ${ }^{11}$ In contrast, the TLC analysis of 8's products revealed only two bands with the upper band (the first product with one IPP condensation) formed earlier and the lower band (the second product with two IPP incorporated) generated much later. The measurement of mass (parent peak $m / z=625.41$ ) of the initial product confirms that the upper band represents the product of compound $\mathbf{8}$ with a single IPP (see Figure S2 of the Supporting Information). Apparently, the bulky coumaryl group interferes with the relocation of the first condensation adduct thereby resulting in the single IPP condensation adduct as primary product. Also judging from the TLC data, the rate constant for the first IPP condensation of $\mathbf{8}$ measured under the single-turnover condition is approximately $0.17 \mathrm{~s}^{-1}, 15$-fold slower than using FPP as a substrate.

Fluorescence Titration of 8 with UPPs and FPP. Fluorescence spectrophotometer was employed to monitor the change of compound $\mathbf{8}$ fluorescence after adding UPPs to the solution containing 8. As shown in Figure 3A, the fluorescence of 1 

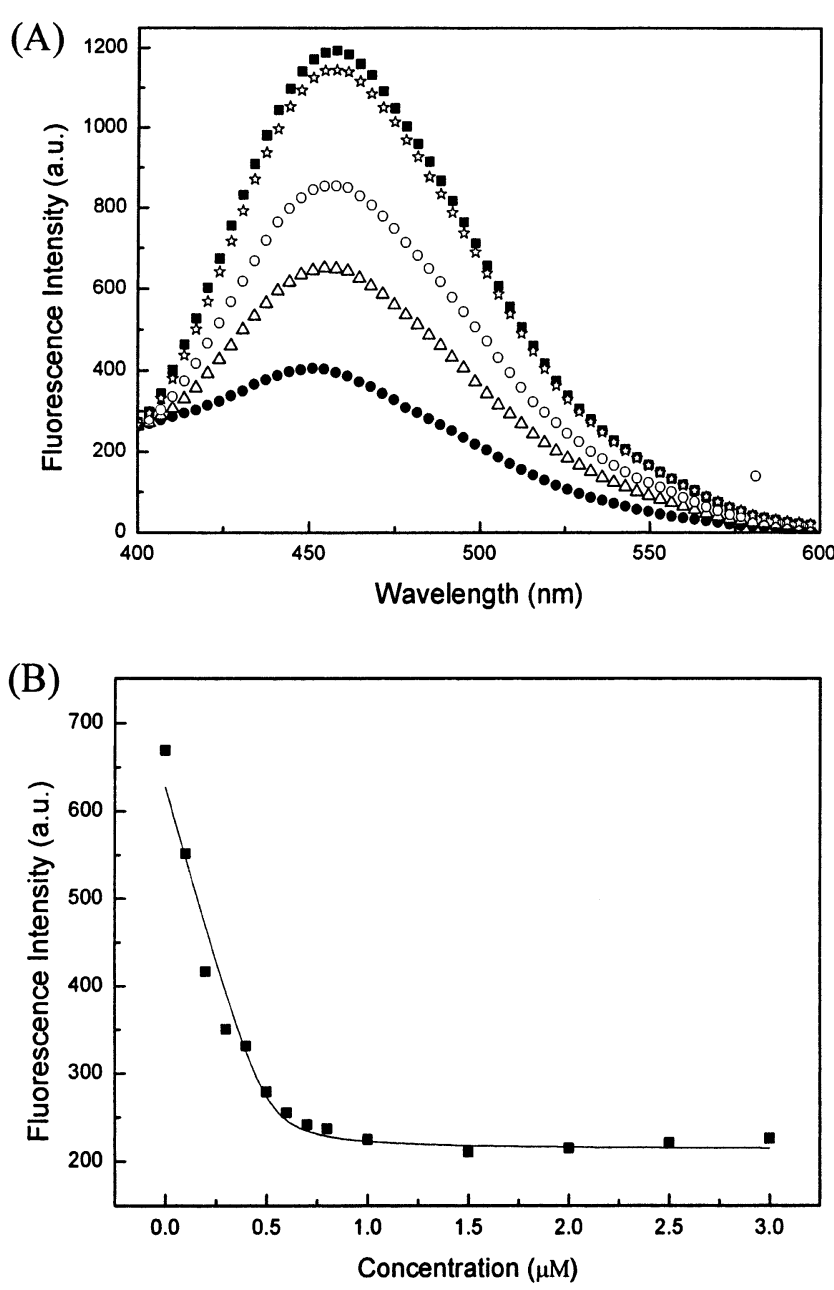

Figure 3. (A) Fluorescence spectra of $1 \mu \mathrm{M}$ compound $\mathbf{8}(\mathbf{\square})$, with addition of $1 \mu \mathrm{M}$ UPPs $(\bullet)$, and after addition of $0.6(\triangle), 1.2(\bigcirc)$, and $3 \mu \mathrm{M}$ FPP $(\star)$. The enzyme quenches the fluorescence intensity of compound $\mathbf{8}$ and the fluorescence is gradually recovered by adding FPP to replace the fluorescent compound from the enzyme active site. (B) The fluorescence titration to determine the stoichiometry for the interaction of $\mathbf{8}$ with UPPs. The fluorescence intensity of $\mathbf{8}(0.5 \mu \mathrm{M})$ is decreased with addition of UPPs solution $(0.2-3 \mu \mathrm{M})$. The titration shows a 1:1 stoichiometry for the binary complex of enzyme and $\mathbf{8}$.

$\mu \mathrm{M} 8(\square)$ is decreased upon addition of $1 \mu \mathrm{M}$ UPPs $(\mathbf{0})$ and gradually recovered by adding $0.6(\triangle), 1.2(\bigcirc)$ and $3 \mu \mathrm{M}$ FPP $(\star)$ to replace bound compound $\mathbf{8}$. This suggests that $\mathbf{8}$ competes the same site on the enzyme with respect to FPP.

Because UPPs can quench 8's fluorescence intensity, the titration experiment by stepwise addition of the enzyme $(0.2-3$ $\mu \mathrm{M})$ into solution of $\mathbf{8}(0.5 \mu \mathrm{M})$ was performed. The equilibrium dissociation constant $\left(K_{\mathrm{d}}\right)$ calculated from the titration curve (Figure 3B) was inaccurate due to the limiting asymptotes for tight binding. The accurate determination of $K_{\mathrm{d}}$ using much lower concentration of $\mathbf{8}$ was hampered by the small fluorescence intensity change. As shown in Figure 4B, $0.5 \mu \mathrm{M}$ UPPs almost completely quenches the fluorescence of $0.5 \mu \mathrm{M}$ compound $\mathbf{8}$, indicating the stoichiometry for the binding of $\mathbf{8}$ to UPPs as $1: 1$.

Kinetics of 8 Association and Dissociation. The binding process of UPPs with $\mathbf{8}$ was monitored by using the stoppedflow spectrofluorimeter. A representative stopped-flow trace obtained by mixing $0.5 \mu \mathrm{M}$ compound 8 with equal volume of $5 \mu \mathrm{M}$ UPPs is shown in Figure 4A $\left(k_{\mathrm{obs}}=379 \pm 42 \mathrm{~s}^{-1}\right)$. The

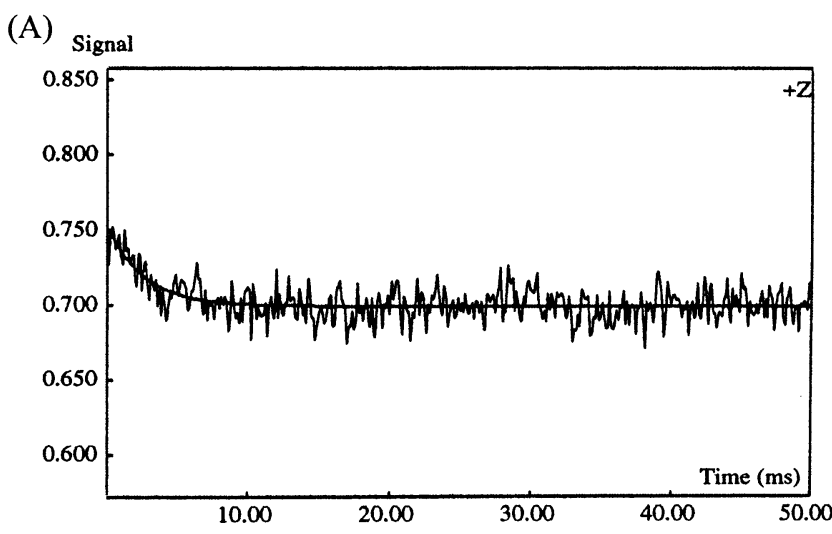

(B)

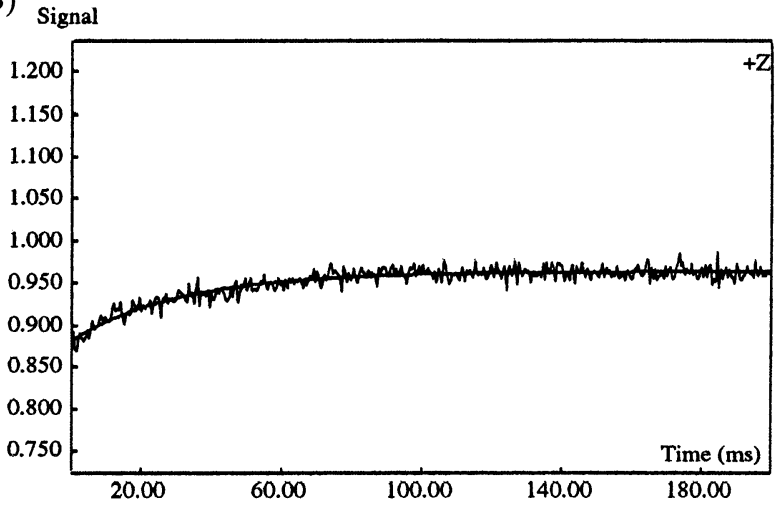

Figure 4. (A) Measurement of the apparent on rate for 8 binding to UPPs. A representative stopped-flow trace by mixing equal volume of UPPs (5 $\mu \mathrm{M})$ with compound $8(0.5 \mu \mathrm{M})$ is shown. The data gave a $k_{\text {obs }}$ of $379 \mathrm{~s}^{-1}$. The dependence of $k_{\mathrm{obs}}$ on protein concentration allowed the calculation of the binding rate constant $\left(k_{\mathrm{on}}\right)$ to be $55.3 \mu \mathrm{M}^{-1} \mathrm{~s}^{-1}$. (B) Determination of the dissociation rate constant for release of $\mathbf{8}$ from UPPs. Using the stoppedflow instrument, the fluorescence increase of mixing UPPs $(0.5 \mu \mathrm{M})$ preincubted with $8(0.75 \mu \mathrm{M})$ with excessive FPP $(25 \mu \mathrm{M})$ was monitored. The stopped-flow data were fitted with a single-exponential eqution to obtain the $k_{\text {off }}$ value $\left(31.6 \mathrm{~s}^{-1}\right)$ of $\mathbf{8}$ dissociation from the enzyme.

observed rate was protein concentration dependent, which was at least 5-fold in excess to ensure the pseudo-first-order condition. The binding rate constant $k_{\text {on }}$ yielded from the slope of observed rate vs UPPs concentration was $55.3 \pm 8.3 \mu \mathrm{M}^{-1}$ $\mathrm{s}^{-1}$ (Figure not shown).

FPP can replace $\mathbf{8}$ from the UPPs active site and cause an increase of fluorescence (Figure 3A). The stopped-flow spectrofluorimeter was utilized to monitored the increase of fluorescence by mixing equal volume of $0.5 \mu \mathrm{M}$ enzyme preincubated with $0.75 \mu \mathrm{M} 8$ with $25 \mu \mathrm{M}$ excessive FPP (Figure 4B). By fitting the data with a single-exponential equation, the rate constant for the dissociation of $\mathbf{8}$ was determined to be $31.6 \pm$ $3.3 \mathrm{~s}^{-1}$.

Substrate and Product Dissociation Kinetics. Using compound $\mathbf{8}$ as a competing agent, the dissociation rate constant of FPP was measured by using stopped-flow (Figure 5A) to be 30 $\mathrm{s}^{-1}$. To further examine whether IPP binding can enhance the FPP affinity and reduce FPP $k_{\text {off }}$, FsPP (a FPP analogue) was utilized. FsPP with a much less labile leaving group serves as an extremely poor substrate for UPPs with the $k_{\text {cat }}$ value of $3 \times$ $10^{-7} \mathrm{~s}^{-1}\left(\mathrm{t}_{1 / 2}=2.3 \times 10^{6} \mathrm{~s}\right) .^{22}$ In the time scale $(0.2 \mathrm{~s})$ of the stopped-flow experiments, FsPP did not react with IPP but only occupied the FPP site. Its dissociation rate constant from the ternary complex (UPPs $•$ FsPP•IPP) or binary complex (UPPs• 


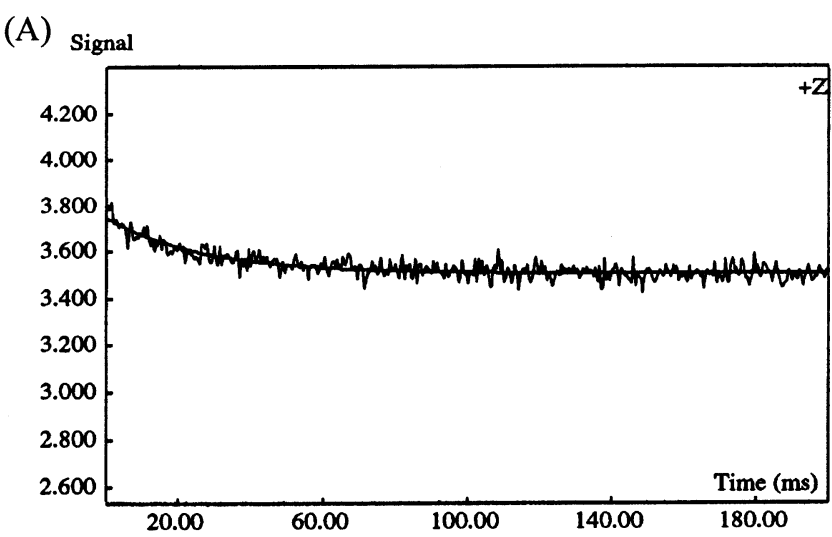

(B)

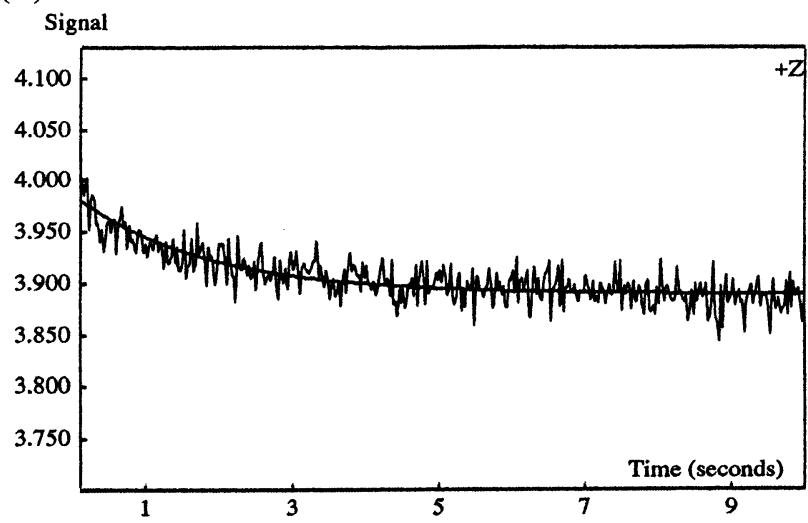

Figure 5. FPP and UPP release rate constants measured from stoppedflow experiments. (A) The $k_{\text {off }}$ of FPP from UPPs $•$ FPP complex was measured by using stopped-flow to mix FPP preincubated with UPPs with compound $\mathbf{8}$. The decrease of compound $\mathbf{8}$ fluorescence was recorded and fitted with a single-exponential equation to obtain the rate constant. (B) The stopped-flow experiment was performed by mixing UPPs·UPP binary complex with excess of $\mathbf{8}$. The data fitted with a single-exponential equation yielded rate constant of $0.5 \mathrm{~s}^{-1}$ for product dissociation.

FsPP) are approximately the same (30 s ${ }^{-1}$, Figure not shown) and similar to that of FPP, indicating no synergistic binding effect.

The fluorescent probe provides a way to measure the UPPs product release rate. By mixing the enzyme preincubated with the $\mathrm{C}_{55}$ product with excess of $\mathbf{8}$ in a competition experiment, the fluorescence intensity was reduced owing to that the free $\mathbf{8}$ became enzyme bound after product release. As shown in Figure $5 \mathrm{~B}$, the product release is slow with a rate constant of $0.5 \mathrm{~s}^{-1}$.

Our previous study has shown that Triton X-100 increases the UPPs $k_{\text {cat }}$ value by accelerating the slow product release and the IPP condensation becomes rate limiting. KINSIM simulation predicted that a $0.4 \mathrm{~s}^{-1}$ product dissociation followed by a $0.001 \mathrm{~s}^{-1}$ conformational change partially limits the steadystate rate of UPPs catalysis in the absence of Triton. In the present stopped-flow study, the product dissociation rate constant $\left(0.5 \mathrm{~s}^{-1}\right)$ is nearly identical with the simulated value. In 1000-s time window, we also observed a stopped-flow trace corresponding to $0.002 \mathrm{~s}^{-1}$. However, compared with the control in which UPPs was not included in the solution, the slow phase with the same amplitude was still observed indicating that the trace may be due to bleaching of $\mathbf{8}$ fluorescence. Next, we carried out the stopped-flow experiments in the presence of Triton to measure the product release rate. The slow product dissociation became faster and the trace in the 10-s window
Scheme 2. Kinetic Pathway of UPPs Catalyzed Reaction

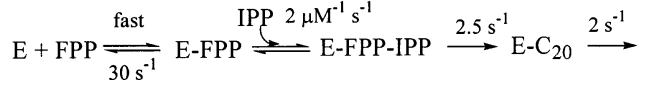

$$
\begin{aligned}
& \text { E- } \mathrm{C}_{25} \stackrel{3.5 \mathrm{~s}^{-1}}{\longrightarrow} \mathrm{E}-\mathrm{C}_{30} \stackrel{2.5 \mathrm{~s}^{-1}}{\longrightarrow} \text { E-C } \mathrm{C}_{35} \stackrel{3 \mathrm{~s}^{-1}}{\longrightarrow} \text { E-C } 40 \stackrel{3.5 \mathrm{~s}^{-1}}{\longrightarrow} \\
& \text { E- } \mathrm{C}_{45} \stackrel{3.5 \mathrm{~s}^{-1}}{\longrightarrow} \mathrm{E}-\mathrm{C}_{50} \stackrel{3 \mathrm{~s}^{-1}}{\longrightarrow} \text { E- } \mathrm{C}_{55} \stackrel{0.5 \mathrm{~s}^{-1}}{\longrightarrow} \mathrm{E}+\mathrm{C}_{55}
\end{aligned}
$$

seen in the absence of Triton disappeared. However, the accurate measurement of the fast product release rate could not be achieved due to the perturbation of fluorescent signal by Triton in a short time-scale.

\section{Discussion}

In this study, we have designed and synthesized a FPP analogue with large fluorescence difference between the free and UPPs-bound form. The compound acts as an inhibitor and an alternative substrate with similar affinity to the enzyme as FPP. Although containing coumarin group, the compound is well accommodated in the UPPs active site. Indeed, this compound is also bound to octaprenyl pyrophosphate synthase and Ras farnesyltransferase and its fluorescence is quenched by these prenyltransferases and recovered by adding FPP (Chen et al., unpublished results), suggesting its potential usefulness to study other FPP-binding proteins. Using our synthetic strategy, different fluorophores can also be introduced.

Fluorescent stopped-flow measurements allow the determination of kinetic constants $k_{\text {on }}\left(55.3 \mu \mathrm{M}^{-1} \mathrm{~s}^{-1}\right)$ and $k_{\text {off }}(31.6$ $\mathrm{s}^{-1}$ ) of the FPP analogue 8 interacting with UPPs. The $K_{\mathrm{d}}$ value $(0.57 \mu \mathrm{M})$ calculated from $k_{\text {off }} / k_{\text {on }}$ is consistent with the $K_{\mathrm{m}}$ and $K_{\mathrm{i}}$ value suggesting a simple binding mode for the compound. Triton shows no effect on the binding affinity of compound $\mathbf{8}$ (Triton also did not alter FPP $K_{\mathrm{m}}$ value as shown previously ${ }^{11}$ ). The stoichiometry of the binding determined from fluorescence titration is $1: 1$. Despite the large active site of UPPs, compound 8 binds only to the FPP site. FPP and FsPP with IPP bound in the active site both dissociate from UPPs at the same rate constant $30 \mathrm{~s}^{-1}$.

The kinetic pathway of UPPs reaction in combining the data from this and previous studies ${ }^{11,15}$ is summarized in Scheme 2. Compared to FPPs and Ras farnesyltransferase reactions, UPPs has a much faster substrate dissociation rate. The isotope trapping experiments failed to trap the radiolabeled product with UPPs (data not shown), consistent with the fast release rate of FPP from the enzyme. As the FPP $K_{\mathrm{m}}$ value is small $(0.4 \mu \mathrm{M})$ for UPPs, its $k_{\text {on }}$ is expected to be much faster than in the other cases. Apparently, FPP binds to UPPs in a rapid equilibrium manner. On the basis of the UPPs structure, the enzyme has an exposed cavity with a positively charged cluster formed by several Arg residues to attract FPP that bears negative charges on pyrophosphate moiety. ${ }^{15}$ This explains the fast on rate of the allylic substrate. The FPP and the subsequently formed intermediates in the active site should retain mobility since they need to undergo translocation after each IPP condensation. The fast off rate for the allylic substrate appears to be prerequisite in the UPPs reaction. With the elongated chain length, UPP product release becomes much slower.

The $k_{\text {off }}\left(0.5 \mathrm{~s}^{-1}\right)$ of a slow product release in the absence of Triton was observed by using the stopped-flow instrument. This is consistent with a previously proposed $0.4 \mathrm{~s}^{-1}$ rate constant of product dissociation based on KINSIM simulation of the 
enzyme product formation pattern under multiple-turnover condition. ${ }^{11}$ However, the slow protein conformational change as predicted required for the next enzyme turnover was not observed in the stopped-flow experiments. This indicates that the fluorescent probe binds to the enzyme prior to the protein conformational change and the conformational change does not cause detectable fluorescence change of compound $\mathbf{8}$.

As demonstrated in the present study, the FPP fluorescent analogue is a useful and suitable tool to probe the interactions of the inhibitor (compound 8), substrate (FPP), and product (UPP) with UPPs. As FPP serves as a common starting material of many natural isoprenoids, the fluorescent probe may be useful to study the ligand interaction of other FPP-binding proteins, particularly when the isotope trapping experiments fail to measure the fast dissociation rate constant of substrate. When some of the prenyltransferases are drug targets, the fluorescencebased assay can be potentially used to discriminate noncompeti- tive from the competitive inhibitors with respect to FPP substrate because the former should not displace the fluorescent analogue from the active site and the fluorescence remains unchanged, whereas the later alter the fluorescence.

Acknowledgment. Authors thank Mr. Chung-ho Chang for technical assistance in performing NMR spectroscopic measurements. This work was supported by grants from Academia Sinica and from National Science Council (NSC91-2113-M001-007) to PHL.

Supporting Information Available: Figures showing fluorescence spectra of compound $\mathbf{8}$ under different solvent condition and the mass spectrum of the reaction product of compound $\mathbf{8}$ with IPP are available free of charge via the Internet at http://pubs.acs.org.

JA020937V 